\title{
Factor Affecting Technical Change of Credit Union Co-operative in Upper Northern of Thailand
}

\author{
Aussawin Phaoumnuaywit, Thanes Sriwichailamphan, Nisit Panthamit \\ Chiang Mai University, Chiang Mai, Thailand
}

\begin{abstract}
Credit union co-operatives are organized for supporting poor people who are difficult to find funding sources for improvement their economic security. Majority of the credit unions co-operatives are made up of members who are currently working in the agricultural sectors. However some of credit union co-operatives have members who are working in non-agriculture sectors, they use credit union co-operatives to improve quality as farmer. The main objective in this paper is comparison of technical operation efficiency of the credit unions agriculture and non-agriculture sector with sample size of 170 groups from eight provinces in the upper northern region of Thailand, using the Malmquist Productivity Index Approach.
\end{abstract}

Keyword: efficiency, Malmquist, credit union, agriculture sector, non-agriculture sector

\section{Introduction}

Thailand is in the period of change in economic structure from agricultural to industrial, which results in the steady increase in economic development. It can be seen from the national income per capita that increased from 23,998 THB per year in 1980 to 140,270 THB per year in 2010, or 16.15 percent per year. However, it was noted that the economic growth had been mostly concentrated in Bangkok and its surrounding areas (perimeter) while the others still faced many problems. Particularly in rural areas, the majority of farmers were faced with difficulty of access to capital and also of handling natural environment which was not favorable for agricultural production. Worse than that, people in rural areas were not able to adapt to the changes taking place in society. As a consequence, they faced many problems such as the insufficient income, the disparity of income between urban and rural areas which increased exponentially, and the poverty having spread in rural areas with over 60 percent of the total population. Thus, it can be said that the economic development of the country in recent years has caused the disparity between two groups of people: One with well-being and the other with poverty (NESDB, 2012).

The state itself had been aware of this problem and tried to solve it. As one of the strategies defined in the National Economic and Social Development Plan No. 9, a solution the government used was supporting people in rural areas to set up community businesses. A goal was to use the businesses to provide people in rural areas the opportunities to access funding sources, production, and marketing. And, business organization most set up was "microfinance institutions" or, popularly called, "savings group", which was supported by the government agencies such as Community Development Department, as well as private organizations such as Credit Union

Aussawin Phaoumnuaywit, Master Degree Student, Faculty of Economics, Chiang Mai University.

Thanes Sriwichailamphan, Ph.D., Associate Professor, Faculty of Economics, Chiang Mai University.

Nisit Panthamit, Ph.D., Associate Professor, Faculty of Economics, Chiang Mai University. 
League of Thailand Limited. Despite different, namely, community bank, production savings group, and credit union, the savings group established in Thailand has the same goal that is to tackle poverty and to help increase opportunities to generate income for the poor in rural areas.

The Upper Northern of Thailand is another area where the majority of residents are farmers. They earn insufficient income and have much debt. As a result, the government sector and the private sector supported the people in each area in setting up savings groups for use as the low-interest financing, the opportunity providing center, and the learning center to improve the quality of life. The savings group mostly set up popular in the upper Northern of Thailand was the savings for production group supported by Community Development Department and the credit union supported by to Credit Union League of Thailand Limited.

However, by comparing operation and performance of each type of savings groups, it was found that the credit union had taken an important role in substantially resolving poverty for the poor. That was because all administration processes of the credit union would be monitored. To recruit qualified members, membership must be considered by the commission to and legally registered. Moreover, it was stated that the credit union could be develop into cooperatives in the community and was the financial institution established under the Cooperative Act 1999 (Chuemuangphan, 2000). Despite the number of production savings group that was higher than that of the credit union in each province in the Upper Northern of Thailand, the number of members and the working capital of the credit unions were still higher than those of the savings group for production. That was the result of the openness of subscriptions and the non-limitation of operation space. Plus, the operation capital of the credit unions in the Upper Northern currently exceeded 7.6 billion baht and the number of the members was more than 250,000 people. In addition, the credit union could continue to expand in different areas (Wichalai, 2002). This would result in the expansion of community economic activities and the better quality of life of the people.

Although there had been the credit unions established widely throughout the Upper Northern of Thailand, the number of people suffering poverty was still high. It might be because the operation of the savings group, which could not be adapted to the ongoing changes in economy, social, technology, and innovation, when compared with the saving cooperatives implementing similar operation process. Therefore, it is important to measure the performance of the credit unions in order to see faults and to reflect on the actual operation. Likewise, the operation technical efficiency of the credit unions set up in the Upper Northern of the country should be studied. This is owing to the fact that the effectiveness of the operation will result in the credit union's strength and capability of adapting to various changes. Last but not least, it is also a must to explore factors affecting the technical efficiency of the credit union's operation.

\section{Objective of Study}

The objectives of this study are the following:

(1) To demonstrate the change in the operation technical efficiency of the credit unions.

(2) To point out the factors affecting the technical change in the operation of the credit unions.

\section{Literature Review}

\section{Measurement of Micro Finance Institution Efficiency}

It is important to measure the operation efficiency of financial organizations so that the ability to manage the resources can be explored. That is why there are many studies putting an emphasis on such a measurement 
such as Haq, Skully, and Pathan (2010) had implemented the data envelope analysis to analyze the operation efficiency of community financial institutions in Bangladesh, the 2011 study on the scalability and performance of the community financial institutions conducted by implementing the stochastic frontier analysis of Lensink and Meesters (2011), and the study of Louis, Seret, and Baesens (2013) on financial performance and social impact of the financial community institutions done by using independent management plan. Meanwhile, analyzing the relation between interest rates and legally acceptable profits, Roberts (2013) explored the profit adjustment of the community financial institutions and the interest efficiency by using Ordinary Least Squared (OLS) concept. And Kipesha (2010) measured the performance of the community financial institutions in Tanzania by adopting the concept of Balanced scorecard with five dimensions including financial dimension, social dimension, user dimension, learning dimension, and organization processes dimension. Tchuigoua (2015) studied the factors determining the quality of supervising the community financial institutions by using the OLS model.

\section{Input and Output Selection}

Financial institutions are intermediary institutions to help transfer purchasing power from those with power purchasing (excess equity) to those without power purchasing (Kipesha, 2010). Most studies on the measurement of the financial institutions' efficiency applied variables of financial ratios. However, to think that it is possible to get correct results by only considering those variables is a misunderstanding (Von Stauffenberg et al., 2003). There are many studies using variables of other ratios, such as the assets, and the institutions' resources, and applying them for the analysis, both Data Envelopment Analysis (DEA) and Stochastic Frontier Analysis (SFA) (Bassem, 2014) which are the non-parametric methods. So, it is necessary to use many important factors in the analysis of the decision making unit efficiency. The factors include inputs and outputs which had been selected for the study and were listed in Table 1.

Table1

Input and Output Selection

\begin{tabular}{|c|c|c|c|}
\hline Author & Research instrument & Input & Output \\
\hline Chen et al. (2008) & DEA - BSC & $\begin{array}{l}\text { - Employee numbers } \\
\text { - Bank Asset } \\
\text { - Bank Deposit }\end{array}$ & $\begin{array}{ll}\text { - } & \text { Bank Loan } \\
\text { - } & \text { Members households } \\
\text { - } & \text { Fee Income }\end{array}$ \\
\hline \multirow[b]{2}{*}{ Giokas (2008) } & \multirow[b]{2}{*}{ DEA } & \multicolumn{2}{|c|}{ Production Efficiency } \\
\hline & & $\begin{array}{l}\text { - Personnel costs } \\
\text { - Running and other operating costs }\end{array}$ & $\begin{array}{l}\text { - Value of loan portfolio } \\
\text { - Value of deposits } \\
\text { - } \quad \text { Non-interest income }\end{array}$ \\
\hline \multirow[b]{2}{*}{ Giokas (2008) } & \multirow[b]{2}{*}{ DEA } & \multicolumn{2}{|c|}{ Transaction efficiency } \\
\hline & & $\begin{array}{l}\text { - Personnel costs } \\
\text { - Running costs and other operating costs }\end{array}$ & $\begin{array}{l}\text { - Loan transactions } \\
\text { - Deposit transactions } \\
\text { - Remaining transactions }\end{array}$ \\
\hline $\begin{array}{l}\text { Chuamuangphan et al. } \\
\text { (2012) }\end{array}$ & DEA & $\begin{array}{l}\text { - Deposit of Members } \\
\text { - Total Expenses } \\
\text { - Savings Group's Capital } \\
\text { - Employee numbers }\end{array}$ & $\begin{array}{l}\text { - } \text { Cash/Deposit } \\
\text { - } \text { Credit Receivables } \\
\text { - } \text { Total Revenue } \\
\text { - Savings Group's Investment } \\
\text { - Number of Members }\end{array}$ \\
\hline Bassem (2014) & $\begin{array}{l}\text { DEA - Malmquist } \\
\text { Index }\end{array}$ & $\begin{array}{l}\text { - Operating Expenses } \\
\text { - Employee numbers }\end{array}$ & $\begin{array}{l}\text { - Interest and Fee Income } \\
\text { - } \text { Gross loan portfolio } \\
\text { - Number of loan }\end{array}$ \\
\hline
\end{tabular}




\section{Methodology}

\section{Step 1: Analysis of Malmquist Productivity Index}

This study used to measure productivity change by Malmquist Total Factor Productivity (TFP) index is usually applied to analyze the panel data. Consider a number of $j=1, \ldots, J$ and time period is $t=1, \ldots, T$ by using $n$ inputs to produce $m$ outputs and the production technology in time period $t\left(S^{t}\right)$ as the equation (1),

$$
S^{t}=\left\{\left(x^{t}, y^{t}\right) \mid x^{t} \text { can produce } y^{t}\right\}
$$

where $x^{t} \in R_{+}^{n}$ and $y^{t} \in R_{+}^{m}$ are input and output vectors. The output distance function at time $t$ represent by the equation (2),

$$
D_{0}^{t}\left(x^{t}, y^{t}\right)=\inf \left\{\theta \mid\left(x^{t}, y^{t} / \theta\right) \in S^{t}\right\}
$$

where $D_{0}^{t}$ denotes the output-based distance function.

Malmquist index (Färe et al., 1994) is defined by using the Distance Function and by considering the difference of the two periods as represented by the equations (3) and (4).

$$
D_{0}^{t}\left(x^{t+1}, y^{t+1}\right)=\inf \left\{\theta \mid\left(x^{t+1}, y^{t+1} / \theta\right) \in S^{t}\right\}
$$

and

$$
D_{0}^{t+1}\left(x^{t}, y^{t}\right)=\inf \left\{\theta \mid\left(x^{t}, y^{t} / \theta\right) \in S^{t+1}\right\}
$$

Distance function is a function that defines the maximum ratio of change in the output expected as $\left(x^{t+1}, y^{t+1}\right)$ in comparison with the technology at the time period $\tau$. Additionally, the distance function can also be used to measure the maximum ratio of change in the output expected as $\left(x^{t}, y^{t}\right)$ in comparison with the technology at the time period $t+1$. This is therefore the analysis of efficiency with the output oriented; and the Malmquist productivity change index can be represented by the equation (5).

$$
\begin{gathered}
M I_{0}\left(x^{t+1}, y^{t+1}, x^{t}, y^{t}\right)=\left[\frac{D_{0}^{t}\left(x^{t+1}, y^{t+1}\right)}{D_{0}^{t}\left(x^{t}, y^{t}\right)} \frac{D_{0}^{t+1}\left(x^{t+1}, y^{t+1}\right)}{D_{0}^{t+1}\left(x^{t}, y^{t}\right)}\right]^{\frac{1}{2}} \\
=\frac{D_{0}^{t+1}\left(x^{t+1}, y^{t+1}\right)}{D_{0}^{t}\left(x^{t}, y^{t}\right)}\left[\frac{D_{0}^{t}\left(x^{t+1}, y^{t+1}\right)}{D_{0}^{t+1}\left(x^{t+1}, y^{t+1}\right)} \frac{D_{0}^{t}\left(x^{t}, y^{t}\right)}{D_{0}^{t+1}\left(x^{t}, y^{t}\right)}\right]^{\frac{1}{2}}
\end{gathered}
$$

Terms in parentheses show technical efficiency changes during period $t$ and $t+1$. Hence, the Malmquist productivity change or the total factor productivity change includes the change of efficiency as in the equation (6) to measures the efficiency change between time period $t$ and $t+1$,

$$
\text { Technical efficiency change }(\mathrm{EFFIC})=\frac{D_{0}^{t+1}\left(x^{t+1}, y^{t+1}\right)}{D_{0}^{t}\left(x^{t}, y^{t}\right)}
$$




$$
\text { EFFIC }=\left[\frac{D_{V R S}^{t+1}\left(x^{t+1}, y^{t+1}\right)}{D_{V R S}^{t}\left(x^{t}, y^{t}\right)}\right]\left[\frac{D_{C R S}^{t+1}\left(x^{t+1}, y^{t+1}\right)}{D_{C R S}^{t}\left(x^{t}, y^{t}\right)} \frac{D_{V R S}^{t}\left(x^{t}, y^{t}\right)}{D_{V R S}^{t+1}\left(x^{t+1}, y^{t+1}\right)}\right]
$$

and the technical change as in the equation (7) to measures the shift in the production frontier between two time periods

$$
\text { Technical Change (TEC) }=\left[\frac{D_{0}^{t}\left(x^{t+1}, y^{t+1}\right)}{D_{0}^{t+1}\left(x^{t+1}, y^{t+1}\right)} \frac{D_{0}^{t}\left(x^{t}, y^{t}\right)}{D_{0}^{t+1}\left(x^{t}, y^{t}\right)}\right]^{\frac{1}{2}}
$$

As mentioned earlier, technical efficiency change (EFFIC) can be divided into two parts: The pure efficiency change (PE) and the scale efficiency change (SE), which can be determined by the equations (8) and (9).

$$
\begin{gathered}
\text { Pure Efficiency Change (PE) }=\left[\frac{D_{V R S}^{t+1}\left(x^{t+1}, y^{t+1}\right)}{D_{V R S}^{t}\left(x^{t}, y^{t}\right)}\right] \\
\text { Scale Efficiency Change(SE) }=\left[\frac{D_{C R S}^{t+1}\left(x^{t+1}, y^{t+1}\right)}{D_{C R S}^{t}\left(x^{t}, y^{t}\right)} \frac{D_{V R S}^{t}\left(x^{t}, y^{t}\right)}{D_{V R S}^{t+1}\left(x^{t+1}, y^{t+1}\right)}\right]
\end{gathered}
$$

While $D_{C R S}$ refers to constant returns to scale distance function and $D_{V R S}$ means variant returns to scale distance function. Thus, the Malmquist productivity Index can be written as the equation (10)

$$
\text { Malmquist productivity Index }=E F F I C \times P E \times S E
$$

However, the value of the Malmquist productivity Index above is more than $1\left(M I_{0}>1\right)$. That means the growth in the Total Factor Productivity (TFP) of the making decision unit (MDU). In other words, over certain period of time, the efficiency develops. Or else, the index value lower than 1 means the inefficiency of the operation over time.

\section{Step 2: Analysis of Factor Affecting to Technical Change}

The Tobit Model for analysis of factor affecting the technical change and the independent variables used in analyzing the impact of the financial variables on the technical efficiency change include both quantitative variables. The model is expressed as follow:

$$
T E C_{i t}=Z_{i t} \beta_{i}+\varepsilon_{i t}
$$

where

$T E C_{i t}=$ Technical Change (MalmquistIndex: $M I$ )

$\beta_{i}=$ Coefficient of Factor Affecting Technical Change

$Z_{i t}=$ Vector of Factor Affecting Technical Change Type $i$

$R O A=$ Return on Total Assets

$R O E=$ Return on Equity

$C S M=$ Capital stock per member

$L M=$ Lending per member 


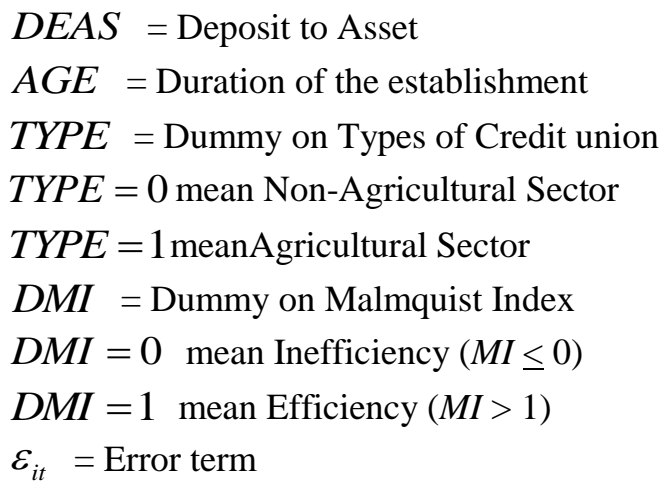

\section{Data and Variables}

The data used in this study covers the performance of the credit unions from 2008-2012 compiled by the Cooperative Auditing Department. The complete set includes the information of 170 cooperative groups including 136 agriculture credit unions and 34 non-agriculture credit unions. The data used in the analysis includes 2 output variables and 3 input variables; and those net profit, lending, capital stock, deposit and expenses, respectively. The net profit represents yearly accounting operating results of the credit unions while the loan suggests the amount of money to lend to their members. The capital stock represents the source of capital; and deposit shows destination of the capital. Last but not least, the expenses represent the operation cost of the cooperatives.

\section{Empirical Results}

The results obtained from the analysis by adopting the Malmquist productivity approach with the financial variables mentioned above. In case the derived Malmquist Index is greater than 1, it represents the operation efficiency of the decision making unit. In contrast, if the value of the index is less than 1 , it indicates the inefficiency. And, when the value equals 1 , it indicates no change. Table 2 shows the change in efficiency, technological change, pure efficiency change, the scale efficiency change, and the total factor productivity, of the unions. It was found that the index value of the credit unions in the agricultural sector was equal to 1.009 on the average. That suggested, overall, the performance of the credit unions in the agricultural sector. On the contrary, the index average of 0.998 of the credit unions in non-agricultural sector indicated their inefficient operation (see Table 2).

Table 2

Productivity Change for Each Types of Credit Union Co-operative

\begin{tabular}{llllll}
\hline & EFFIC & TEC & PE & SE & TFP \\
\hline Agriculture Sector & 1.026 & 1.001 & 1.034 & 0.983 & 1.009 \\
Non-Agriculture Sector & 1.078 & 0.928 & 0.977 & 1.102 & 0.998 \\
Geometric Mean & 0.977 & 0.975 & 0.991 & 0.986 & 0.953 \\
\hline
\end{tabular}

Note. Source: Survey and calculation.

However, by considering percent of the efficient unions and the inefficient unions, the results pointed out the percent of the credit unions with efficiency and those with no efficiency in the agricultural sector of 52.17 and of 47.83 respectively. Meanwhile, the percent of those in the non-agricultural sector went in the same way. That was, the percent of the credit unions with efficiency and those with no efficiency were 58.82 and 41.18 in 
order (see Table 3).

\section{The Study on the Factors Affecting Technical Efficiency Change}

The independent variables used in analyzing the impact of the financial variables on the technical efficiency change include both quantitative variables which are return on asset $(R O A)$, return on equity $(R O E)$, share stock per member $(C S M)$, lending per member $(L M)$, duration of established $(A G E)$, the ratio of deposit to asset (DEAS), types of credit union (TYPE with agriculture and non-agriculture), feature of Malmquist Index (DMI with more than one and other). In addition, in order to obtain the accurate result, the number of the members of the credit unions, as the important factor suggesting the capital source, the capital destination, and the scale of the group, was also respected.

Table 3

Proportion of Credit Union Co-operatives' Efficiency

\begin{tabular}{llll}
\hline & Efficiency & Inefficiency & Total \\
\hline Agriculture Sector & 47.83 & 52.17 & 100.00 \\
Non- Agriculture Sector & 41.18 & 58.82 & 100.00 \\
\hline
\end{tabular}

Note. Source: Survey and calculation.

Table 4

Factor Affecting in Productivity Change

\begin{tabular}{|c|c|c|}
\hline Variables & Coefficient & Standard Error \\
\hline$\overline{\text { (Constant) }}$ & $0.4461^{*}$ & 0.2684 \\
\hline$R O A$ & $-9.7600^{*}$ & 5.0524 \\
\hline$R O E$ & $7.1456^{* *}$ & 3.1608 \\
\hline$A G E$ & -0.0082 & 0.0086 \\
\hline$C S M$ & $1.57 \mathrm{E}-05^{*}$ & 9.22 E-06 \\
\hline$L M$ & -1.85 E- $05^{* * *}$ & 6.29 E-06 \\
\hline$D E A S$ & $-0.5124^{*}$ & 0.2979 \\
\hline TYPE & $0.4698^{* * *}$ & 0.1755 \\
\hline$D M I$ & $3.0238^{* * *}$ & 0.1267 \\
\hline
\end{tabular}

Notes. ${ }^{* * * * * * *},{ }^{*}$ denote significance at the $0.01,0.05$, and 0.10 levels of Z-statistic, respectively. Dependent variable is Productivity Change or Malmquist Index $(M I)$.

The results showed that ROA, ROE, CSM, LM, DEAS, TYPE and DMI significantly affected Total Factor Productivity or Malmquist Index (MI) (see Table 4). To be specific, return on asset (ROA) inversely affected $M I$ since loan is the most share of asset which related with lending to member ( $L M$ ) had an impact on $M I$ inversely. It was indicated that more lending would cause less efficiency of the groups since most of the receivables had yet no capability of repaying on schedule. Moreover, return on equity $(R O E)$ affected $M I$ with direct variation. That was, the increase in return on equity could increase the performance of the cooperatives. Because of when their groups had more capital to spend in operation, they could improve the facilities in organization or set a new policy to aid their members as well. Also, share stock per member (CSM) affected $M I$ with the direct variation; and this result demonstrated that a larger number of share stock would consequently enhance the operation efficiency of the credit unions due to the rise in their liquidity and the opportunity to improve performance of organization and members' quality of life. In addition, we also considered on member's deposit since it is source of capital and found that the ratio of member's deposit to asset (DEAS) 
affected $M I$ inversely. It means that deposit ratio on asset is high, the efficiency will be less. At any rate, it was proved that types of credit union had no significant effect on the operation efficiency. This is consistent with the analysis of the technical efficiency and the percent of the credit unions with and without efficiency as mentioned above.

\section{Conclusion}

Although the value of the Malmquist index or the total factor productivity (TFP) of the agriculture credit unions is higher than that of the non-agriculture credit unions, it is to be noted that the difference between the two values is not significantly distinct. This suggests that there is no difference in performance between them. Thus, the way to develop the credit unions should be the emphasis on recapitalization by promoting member's savings in form of share capital and defining clear terms of borrowing. It is also important to educate the members about the money management so that they can wisely spend the money lent by the cooperatives. Consequently, this will help reduce the problem about their ability to repay their debt and also will make the credit union become the sustainably stable financial institution in the future.

\section{References}

Annabel, V. (2008). What macro factors make microfinance institutions reach out? Retrieved from https://dipot.ulb.ac.be/dspace/bitstream/2013/14665/1/rou-0241.pdf

Anthong, A., \& Khawsa-ad, M. (2009). The efficiency change of hotel management in Chiang Mai. Thammasat Economic Journal, 27(3), September 2009. (in Thai).

Bassem, B. S. (2014). Total factor productivity change of MENA microfinance institutions: A Malmquist productivity index approach. Economic Modelling, 39, 182-189.

Chen, T. Y., Chen, C. B., \& Peng, S. Y. (2008). Firm operation performance analysis using data envelopment analysis and balanced scorecard: A case study of a credit cooperative bank. International Journal of Productivity and Performance, 57(7), 523-539.

Chuamuangphan, A. et al. (2012). Economic efficiency of saving groups in upper northern region. Maejo University, Chiang Mai, Thailand.

Chuemuangphan, A. (2000). Money and Banking. Maejo University, Chiang Mai, Thailand.

Cooper, W. W., Seiford, L. M., \& Tone, K. (2007). Data envelopment analysis: A comprehensive text with models, applications, references and DEA-Solver software. New York: Springer.

Credit Union League of Thailand Limited. (2014). Credit union's operation results in upper northern of Thailand. Retrieved from http://www.cultthai.coop/new/images/stat57/size_1257/s1257_09.pdf

Färe, R., Grosskopf, S., Norris, M., \& Zhang, Z., (1994). Productivity growth, technical progress and efficiency change in industrialized countries. Am. Econ. Rev., 84, 66-83.

Giokas, D. I. (2008). Assessing the efficiency in operations of a large Greek bank branch network adopting different economic behaviors. Economic Modelling, 25(3), 559-574.

Gutiérrez-Nieto, B., \& Serrano-Cinca, C. (2007). Factors explaining the rating of Microfinance institution. Nonprofit and Voluntary Sector Quarterly, 36(3), 25.

Haq, M., Skully, M., \& Pathan, S. (2010). Efficiency of microfinance institutions: A data envelopment analyses. Asia Pac. Financ. Markets, 17, 63-97.

Hartarska, V. (2005). Governance and performance of microfinance institutions in Central and Eastern Europe and the Newly Independent State. World Development, 33(10), 1627-1643.

Hermes, N., \& Lenssink, R. (2009). Financial development and the efficiency of microfinance institutions. SSRN eLibrary.

Jonathan Adongo, C. S. (2005). Factors influencing the financial sustainability of selected microfinance institutions in Namibia. The Namibian Economic Policy Research Unit.

Jonathan, M. (1998). Does microfinance really help the poor? New Evidence from Flagship in Bangladesh, Princeton University, Woodrow Wilson School of Public and International Affairs, Research Program in Development Studies. 
Kipesha, E. (2010). Global financial crisis: Impact on bank's financial intermediation role, evidence from commercial banks in Tanzania. Account. J. 26, 22-34.

Kumar, A. P. (2007). A critical analysis of Micro finance in India. Business school.

Lafourcade, A. L., Isern, J., Mwangi, P., \& Brown, M. (2005). Overview of the outreach and financial performance of Microfinance institution in Africa. Retrieved from http://afraca.org/download/afraca_kmp's_regional_experiences/Outreachand-Financial-Performance-of-Microfinance-Institutions-in-Africa-An-Overview-by-Anne-Lucie-Lafourcade-et-al.pdf

Lensink, R., \& Meesters, A. (2011). Outreach and efficiency of microfinance institutions. World Development, 39(6), 938-948.

Louis, P., Seret, A., \& Baesens, B. (2013). Financial efficiency and social impact of microfinance institutions using self-organizing maps. World Development, 46, 197-210.

Manlagnit, M. C. V. (2004). The role of other economically active household members in poverty Alleviation. Retrieved from http://dirp4.pids.gov.ph/ris/dps/pidsdps0403.pdf

Office of the National Economic and Social Development Board (NESDB). (2012). Poor people share. Retrieved from http://social.nesdb.go.th/social/Portals/0/ Poverty\%20Report\%202555.pdf

Roberts, P. W. (2013). The profit orientation of microfinance institutions and effective interest rates. World Development, 41, 120-131.

Tchuigoua, H. T. (2015). Determinants of the governance quality of microfinance institutions. The Quarterly Review of Economics and Finance, 58, 32-43.

Von Stauffenberg, D., Tor, J., Naomi, K., \& María, C., (2003). Performance indicators for microfinance institutions: A technical guide (3rd ed.). MicroRate \& IDB, Washington, D. C.

Wichalai, K. (2002). Adopted credit union co-operative of citizen in Chiang Mai and Lamphun Province (pp. 1-5). Maejo University.

Wijesiri, M., \& Meoli, M. (2015). Productivity change of microfinance institutions in Kenya: A bootstrap Malmquist approach. Journal of Retailing and Consumer Services, 15, 115-121. 